\title{
Bua-mi: Learning through Meaningful Outdoor Activities
}

\author{
Joseph Gibson, Kari Schjøll Brede, Grete A. Steigen
}

\begin{abstract}
This paper reflects on a long term and on-going project that used the Scandinavian "friluftsliv" (nature living) concept and meaningful work in the outdoors as a medium for language development with two young adults who are congenitally deafblind. The physical nature of the project was key to both participants developing their tactile language.
\end{abstract}

\section{Keywords}

Language development, tactile language, outdoor activities, friluftsliv, deafblind, communication. 


\section{Introduction}

This paper reflects on a long term, and still ongoing project that used the Scandinavian "friluftsliv" (nature living) concept and meaningful work in the outdoors as the medium for language development with two young adults who are congenitally deafblind (CDB).

The aim of the project was to design an activity that was possible to understand through the tactile sense, creating the best possibilities for language development. There was an interest in the meeting between the non-formal language, used by the participants (bodily tactile expressions), and the formal language (Norwegian Tactile Sign Language and spoken Norwegian), used by the professionals. The project has previously been the subject of reports written in Norwegian focusing on meaningful activities and language development (Brede, 2013; Brede, 2014)

There were two participants in the project. Tormod (25 years) has CHARGE syndrome, he is completely blind with residual hearing on right side, 60-80 db. Petter (15 years), has no specific diagnosis, is completely blind, but has some useful hearing. He seems to understand spoken language, but has difficulties expressing verbal language himself. Both Tormod and Petter walk with a guide and stand independently. Both Petter and Tormod are classified as "deafblind". Throughout this paper the participants Tormod and Petter, are referred to by their real name. Both sets of parents were happy for this to be the case, as was Petter himself.

Deafblindness is a combined vision and hearing impairment of such severity that it is hard for the impaired senses to compensate for each other. Thus, deafblindness is a distinct disability. Deafblindness falls into one of two categories; acquired or congenital. That is to say when the dual sensory impairment (deafblindness) began. People are referred to as congenitally deafblind (CDB) if their impairments were present from birth or before language was acquired. However, different levels of impairment, and causes of impairment means neither is a homogenous group and abilities in all areas can differ widely.

There are three main challenges that affect all people who are deafblind whether acquired or congenital. The challenges are a) communication and social interaction, b) acquisition of information and c) spatial orientation and moving around freely.

CHARGE syndrome is a rare condition and is one of the most frequent causes of combined sensory loss in the western world. Estimated incidence ca. 1 per 10000 . It is estimated that approximately $60 \%$ of children born with this syndrome have alterations in CHD7 gene. (Andersen \& Klingenberg, 2008). Each letter in the name CHARGE refers to one of the six most common traits:

C Coloboma (kolobom) (column formation in the iris or other parts of the eye)

$\mathrm{H}$ Heart (congenital heart defect) 
A Atresia choanae (narrowed or blocked passage between the nose and throat)

$\mathrm{R}$ Retardation (delayed growth and development)

G Genital hypoplasia (underdevelopment of genitals)

E Ear deformities (malformations of the ear and hearing loss)

Diagnosis is made when one finds 3-4 of these symptoms.

\section{Method}

The following section outlines how the project came about. The initial aims and methods are discussed along with three key features of the project methodology.

\section{Project outline}

The project began with a request from a residential home for a CDB young man (Tormod) living in a rural area. They were aiming for better communication skills for Tormod and for his staff team. His mother believed that her adult son had desire for adventure, learning and a need of social life, despite the fact that he had CHARGE syndrome and deafblindness. His care plan also had a section stating that Tormod was to spend time with the local carpenters as an "apprentice". The combination of staff team who listened to the mother, a culture for outdoor living, and professionals believing in holistic access to the world and physical activity as a key to language all combined to support the mother's ideas. This resulted in the idea of the Bua-mi ("my-house") project. The project selected building a small house as the focus. It was small enough to be tactilely available outside and inside, (you can touch all four walls and roof while standing in one spot inside) and big enough to be useable and meaningful.

The culture for activities existed already, both in a wider context through the Norwegian 'friluftsliv' ('outdoor living') and in a local context. Tormod lives on a farm that was also a tourist centre and his family and staff team all participate regularly in outdoor activities.

The project was based on the ideas that language and cognition are tied to each other (Langacker, 2000; Selvik, 2006) and that outdoor activities benefit communication development with congenitally deafblind people (Gibson, 2005). The Norwegian System for Deafblindness believed in the project and supported it economically. Eikholt, the national resource centre for deafblind, accepted being the project owner.

The project idea was also presented to the leader of the Skådalen School for deafblind and was thought to be interesting for a 15 year old pupil (Petter) and his two teachers to be involved with the project with Tormod. They had higher knowledge in language development but lacked a wider range of meaningful activities to support Petter's language acquisition. 


\section{Project Aim}

The aim for the project was to develop the deafblind participants' communication skills. To do this we had to also develop the skills of their support staff, it was not enough to work only with the two young men. The supporting staff and teachers needed to be taught new ways of "acting", (pedagogical skills such as scaffolding of learning experiences, focusing on the tactile exploration and expressions, more repetition and variation within each topic for example). Most of them also needed communication skills and sign language competence to support their students with deafblindness. Therefore, the project had an underlying aim: to educate the staff and teachers in better practice. (see Table 1).

Table 1.

Project Aims

\section{Project aim}

To develop the deafblind participants communication skills

\begin{tabular}{ll}
\hline Deafblind participant aims & Staff aims \\
\hline Increase social interactions & Learn sign language. \\
$\begin{array}{l}\text { Learn new skills (Meaningful, } \\
\text { understandable, manageable tasks) }\end{array}$ & $\begin{array}{l}\text { Learn how to transfer regular sign } \\
\text { language into tactile sign language suited } \\
\text { for the deafblind participants. }\end{array}$ \\
Increase expressive language. & $\begin{array}{l}\text { Learn how to read deafblind partners own } \\
\text { expressions. }\end{array}$ \\
\hline
\end{tabular}

\section{Project methods}

The Bua-mi project was fortunate in that it ran over an extended period. Initially, as outlined above, the project was run by Eikholt and funded by The Norwegian System for Deafblindness (August 2011 - August 2013). At the end of this period of two years the project continued organised by the Norwegian Labour and Welfare Administration (NAV) for two more years, still run by Eikholt, until June 2015 (NAV is the short name for the). The project contained between three and five "meeting points" with a duration of one week each year. In September 2013 the course was given further impetus when the Deafblind International Outdoor network used Bua-mi as a base for one of their outdoor weeks. This enabled new theories and new perspectives from the participants of the DbI outdoor network. 
Each of the meeting points had a regular outline that enabled all the participants to anticipate what was going to happen both through the week and during each day.

The weekly outline always included a) a trip to explore other houses and cabins in local area, b) collecting materials, including cutting down a tree, c) exploring materials focusing on smell and touch and d) the construction of some part of Bua-mi.

The daily activity outline included a) a morning meeting in LJØRBUA "SMOKE HOUSE" (a small hut with a fireplace next to Tormod's house) to discuss days plans and go through anticipated signs for the day and discussions from the previous evening, b) doing the day's activity (which was filmed), c) immediate review of video data at the end of the practical sessions by the project leader, who selected video clips to share with the staff and d) discussion of video and the implications of possible signs and "proto-signs" uttered by Tormod or Petter. Proto-signs can be explained as tactile signs that are not yet conventionalised through repetitions and use; they are still "in the making" (Ask Larsen 2003).

There were a number of other key project components that contributed to the success of the Bua Mi project: a) experiential learning, b) interdisciplinary collaboration, c) scaffolding, d) use of video recordings and e) use of case studies. Each of which will be discussed more fully below.

\section{Experiential Learning}

Experiential learning or learning by doing was a key aspect of the project for all the participants, deafblind and non-deafblind. Having shared practical experiences upon which to base ensuing conversations was of paramount importance. This could be seen directly as often the signs developed were based on the actual experiences not the conventional sign.

\section{Interdisciplinary collaboration.}

Bringing together different people with different professions and skills and enabling them to cooperate and influence each other was a key aspect to the project. Alongside the two participants with deafblindness there were teachers, carpenters, support staff, consultants and interpreters involved at different points. All participants had influence on the development of the project and everyone's input was valued equally. The project was also used in a Masters project that proposed a new sign category (Forsgren, 2016).

\section{Scaffolding}

The concept of scaffolding or working with zones of proximal development (Vygotsky, 1986) was vital in ensuring the two deafblind participants were fully involved in all aspects of the project. No assumptions about previous knowledge were made and since 
many of the support staff did not have building knowledge, they also had to be scaffolded in the process. The scaffolding was a dynamic process and permeated all aspects of the project for all the participants. Concepts from Engeström's Activity Theory were also useful in helping frame the project for all the participants (Engeström, 1987).

\section{Use of video}

The use of video is assumed to be the best way of studying tactile communication (Nafstad \& Rødbroe, 1999; Mesch, 1994; Raanes, 2006). In this project the analysis of recordings could be described as "fresh": that is, analysed the same day or the day after. This enabled immediate learning from the "performances" (how the activities were performed by all the participants and the interplay between them) captured, giving the opportunity for the learning to be implemented the next day. The experiences are shared and discussed almost in "real time". This overcomes one of the weaknesses that video only captures the visual and audio and not the tactile sense. Reviewing the video fresh gave the best chance for participants to add comments and remember the tactile impressions.

The video footage was also used to show good practice examples to the whole group. The video recordings were also crucial in noticing small "comments" (vocalisations, bodily movements, facial expressions for example) and proto signs from the deafblind participants. This was key as it allowed the support staff to focus on the individual's ways of commenting on the activities, which was not always with the conventional sign.

This project preceded the General Data Protection Regulations, which came into force in Norway in 2018. Nevertheless, in the preceding years and since, if any of the video footage was to be used out with the project setting, to present at a conference for example, permission was sought from the participant or parents where appropriate.

\section{Case studies}

The project comprised of two separate but interlinked cases, Tormod and Petter. Tormod and Petter had separate teams, two different conditions causing their deafblindness, two different histories, differing levels and methods of communication and different prerequisites for learning and language development. They are very different cases that were addressed through the same project at the same time.

Different aspects of the project could also be considered as separate cases, later in this paper we present "sawing" and "nails and screws" as aspects of the project that highlight some of the learning and language development for both Petter and Tormod. 


\section{Findings}

In addition to the aims outlined previously there were many other outcomes and additional beneficiaries. Table 2 shows an overview of all the areas of benefit identified for the different groups of participants in the Bua Mi project.

Table 2.

Outcomes from Bua-mi project

\begin{tabular}{|c|c|c|c|}
\hline $\begin{array}{l}\text { Deafblind } \\
\text { persons }\end{array}$ & Support staff & $\begin{array}{l}\text { Local community } \\
\text { \& Family }\end{array}$ & Professionals \\
\hline $\begin{array}{l}\text { Development of } \\
\text { language }\end{array}$ & $\begin{array}{l}\text { Recognition of } \\
\text { expressions as } \\
\text { language }\end{array}$ & & $\begin{array}{l}\text { Better } \\
\text { understanding of } \\
\text { importance of } \\
\text { meaningful } \\
\text { activities }\end{array}$ \\
\hline Learn skills & Learn new skills & & $\begin{array}{l}\text { Adding to the } \\
\text { knowledge base }\end{array}$ \\
\hline $\begin{array}{l}\text { Subject to talk } \\
\text { about }\end{array}$ & $\begin{array}{l}\text { Subject to talk } \\
\text { about with CDB } \\
\text { partner }\end{array}$ & $\begin{array}{l}\text { Subject to talk } \\
\text { about with CDB } \\
\text { person }\end{array}$ & $\begin{array}{l}\text { Try to find what } \\
\text { makes a good } \\
\text { subject for } \\
\text { conversation with } \\
\text { CDB people }\end{array}$ \\
\hline $\begin{array}{l}\text { Development and } \\
\text { understanding of } \\
\text { signs in context }\end{array}$ & $\begin{array}{l}\text { Improved sign } \\
\text { language skills }\end{array}$ & $\begin{array}{l}\text { Understanding of } \\
\text { sign language }\end{array}$ & $\begin{array}{l}\text { Recognition of } \\
\text { expressions as } \\
\text { language in the } \\
\text { CDB person }\end{array}$ \\
\hline Build relationships & $\begin{array}{l}\text { Positive view of } \\
\text { deafblind partners } \\
\text { communicative } \\
\text { abilities }\end{array}$ & & $\begin{array}{l}\text { Explanation of the } \\
\text { importance of } \\
\text { looking for CDB } \\
\text { persons } \\
\text { communicative } \\
\text { abilities }\end{array}$ \\
\hline $\begin{array}{l}\text { Authentic } \\
\text { experiences }\end{array}$ & & $\begin{array}{l}\text { Meaningful } \\
\text { involvement }\end{array}$ & \\
\hline
\end{tabular}




\begin{tabular}{llll}
\hline $\begin{array}{l}\text { Deafblind } \\
\text { persons }\end{array}$ & Support staff & $\begin{array}{l}\text { Local community } \\
\text { \& Family }\end{array}$ & Professionals \\
\hline $\begin{array}{l}\text { Generate authentic } \\
\text { emotions }\end{array}$ & $\begin{array}{l}\text { Provide the basis } \\
\text { for conversations } \\
\text { about emotions }\end{array}$ & & \\
Understanding of & More holistic & More holistic & Develop learning \\
concepts & $\begin{array}{l}\text { understanding of } \\
\text { the person they }\end{array}$ & $\begin{array}{l}\text { understanding and } \\
\text { positive perception } \\
\text { support }\end{array}$ & techniques \\
& of people with & \\
disabilities & Network building & Network building \\
Network building & Network building & New staff training \\
& Framework for & & opportunities \\
\hline training new staff & & & \\
\hline
\end{tabular}

Space prohibits a discussion of all the outcomes identified so this paper will focus on the language development of the two deafblind participants as this was the overarching aim. A key component of this occurring is the simultaneous tactile language development of the staff.

As noted above the two deafblind participants had two separate teams, two different conditions causing their deafblindness and two different histories, therefore there were different results for each. However, there were some aspects in common for both the deafblind participants and their respective staff teams: a) and increased activity with supporting tactile dialogues, b) increased focus on the participants' own expressions and c) changed attitudes in relation to: a) importance of tactile modality, b) the capacity of the deafblind participants both cognitively and physically and c) a recognition that it is the partners who often cause linguistic limitations.

Table 3 shows some of the identified changes in the individual participants related to communication, all within the "language development" aim. 
Table 3.

Identified changes in the participants related to communication noticed during the project

\begin{tabular}{ll}
\hline Tormod & Petter \\
\hline $\begin{array}{l}\text { He slightly increased expressive } \\
\text { cultural sign vocabulary }\end{array}$ & $\begin{array}{l}\text { He increased expressive cultural sign } \\
\text { vocabulary } \\
\text { Increase in his dialogues }\end{array}$ \\
$\begin{array}{ll}\text { More fluid dialogue with his partners } \\
\text { Increase in the available tactile }\end{array}$ & $\begin{array}{l}\text { Ability to describe emotions and } \\
\text { relationships }\end{array}$ \\
language & $\begin{array}{l}\text { Ability to describe whether he liked the } \\
\text { activity or not }\end{array}$ \\
events & $\begin{array}{l}\text { He described his feeling of relations with } \\
\text { people he met }\end{array}$ \\
His partners sign vocabulary increased phrases that describe & $\begin{array}{l}\text { He wanted to continue with the activity } \\
\text { His partners belief that he CAN }\end{array}$ \\
$\begin{array}{l}\text { PARTICIPATE increased } \\
\text { His gestures and expressions were often } \\
\text { recognised as communicative }\end{array}$ & $\begin{array}{l}\text { He became linguistically conscious and } \\
\text { could expressively choose language } \\
\text { form }\end{array}$
\end{tabular}

He got a feeling of being competent

These aspects identified in the Bua-mi project are supported by the literature. Gibson (2005) has previously shown how three aspects of outdoor activities can be used to develop declarative communication with deafblind adults. This project used these aspects (an interesting subject, authentic feelings and meaningful relationships) over an extended period. In addition, Ask Larsen (2013) discussing the acquisition of a bodilytactile language highlights three paramaters for gaining access to linguistic culture;

(1) availability of linguistic interaction,

(2) meaningfulness in language use, and

3) purpose for communicating on a linguistic level."

(Ask Larsen, 2013, p. 103)

Ask Larsen goes on to identify certain aspects of activities that can support communication development that are present in the activity of the Bua-mi project. 
91 • JDBSC, 2020, Volume 6 Gibson • Bua-mi: learning through meaningful outdoor activities

"What is added to the structure is negotiation of the activity motive and action goal, division of labour, procedure planning, tool-use, and social and societal rules." (Ask Larsen, 2013, p.106)

“...we need to help people who are congenitally deafblind take an increasingly active role in more complex activities [...] we need to make this language use a necessary, accessible, and meaningful part of the activities." (Ask Larsen, 2013, p112)

From the literature we can begin to see which aspects of the Bua-mi Project might have contributed to the communication development noted. The activity was meaningful and authentic (Gibson, 2005), there were elements of procedure planning, tool-use and at times the activities could be complex (Ask Larsen, 2013) and there was a social aspect of working as a group and the resulting development of relationships as well as complying with social and societal rules (Gibson, 2005, Ask Larsen, 2013). The next section presents two examples which will highlight were the findings presented above occur.

\section{Examples}

The project contained a wide range of activities connected to the building of the house. This ranged from the small details in the building of a house, to putting the building in context through excursions to other similar small houses.

Two examples will illustrate some of the findings in the depth, and highlight the points raised from the literature in the previous section. The cases focus on the tactile experience of sawing wood, and the exploration and understanding of screws and nails.

\section{Sawing}

Sawing was a thread through the Bua-mi project. Sawing trees in the forest, making planks from trees at the sawmill, sawing planks and sawing firewood all made stories of sawing. When we include different types of saws like handsaws, chain saws and sawmills, the holistic picture of variations of sawing occurs as well as a grounded understanding of the purpose of sawing.

The sawing stories contained various elements, the movement of sawing, the smell of the wood and the movement (falling) of the wood. One example is when Petter told about his experience of cutting a tree. The teachers had already talked to him about TREE- SAW, TREE - FALL. Petter's story did not only show the form of a tree, the movement of the saw and the tree falling. His signs changed and contained also the direction and speed of how the tree fell from his own tactile perspective. He shows how 
he understands the concept of a tree, the results of his actions (sawing) and of language use in a creative and symbolic manner describing the experience.

The experiences included not only the concept of the tree, but also authentic stories about excitement and anticipation. When Petter felt the plank moving when sawing, he could feel the vibration and knew when he supposed it to fall. The repetitions and the experience fascinated him, and his happy expressions were fascinating to observe. The teachers reflected about this and discussed whether they had ever managed to create learning situations making him that happy. An emotional engagement with the activity has also been shown in other situations. Once the carpenter did not show up as expected, Petter was deeply unhappy. It was a difficult situation for him as he was not able to express why he felt so unhappy. He talked about missing his parents and being away from home. The teachers supported Petter after he had calmed down, to create his story about what it was like to be disappointed, that some people are interesting to wait for, and that it hurts when it fails. These types of emotional situations, both happy and sad, are often difficult to create in an ordinary school situation but is an important part of life and learning.

Another incident highlights Tormod's increasing understanding. Tormod was building a wall with his staff and the carpenter. They were sawing a plank, and Tormod was actively following the movements of the saw, partly holding it, partly holding his staff, feeling her movement. When sawing the plank was finished, the end of the plank fell down on the ground. Very quickly the staff picked the off cut from the ground, putting it away as waste. Then we saw in the video Tormod bending down searching the ground. He raised, grabbed the hand of the staff and pointed with their hands together in the direction away from the work (which also is the direction of his home). The staff member immediately interpreted his utterance as "I want to go home", and she tried to convince him to stay. It was while analysing the video later that we detected his intentions, which was not to go home, but to find the part of the plank that fell to the ground; The video showed that Tormod searching the ground was not a random movement, but a systematic such for the interesting plank offcut. Through the video analysis the staff became more attuned to following Tormod's interest and aware of his holistic understanding of the process.

The next day a similar situation was created so that Tormod could discover how the plank falls and where he could find the offcuts, and to make a story about the offcut planks. Tormod again began sawing with the carpenter. We could see Tormod exploring the sawing movement with his forehead as he was leaning against the arm of the carpenter. The plank fell as planned to the ground, and the staff and Tormod were searching for it as planned. They found it, and the staff commented in Norwegian: "The plank fell down, here", as she tactilely showed Tormod where the plank landed. She 
asked him to bring it to upright position with her voice and tactile signing. The way they were standing, the staff holding arms around Tormod, it was not possible for her to see Tormod signing about the sawing he felt on his forehead. The video shows that they brought the plank in an upright position. Tormod leaned over the end of the plank and again signed the sawing-experience on his forehead with his hand. The signing included the sign, where he felt the sign and also where the sawing took place. The staff commented on the plank's upright position with her voice. It was clear the staff has the offcut plank in her mind, while Tormod seemed focused on something else. When the plank was left on the table, Tormod in big and clear movements signed the SAWING on his forehead again. In that moment his staff saw the sign, and it made her wonder. (Her facial expression showed this clearly). The video recording captured it all, and we learned from it how Tormod signed and reflected on the aspects of his experience of sawing. He had the hand shape and movement of sawing, placed on his forehead as the articulation place, where he also explored the sawing tactilely. By analysing the video, we could better understand his utterances. Some days later, Tormod is sawing with two of his staff (this time different people, but informed through the video analysis, about the signing the previous days). They are sawing chipboard together. Tormod was feeling the saw and the chipboard which was supported in the arms of one of the staff. The other staff member was standing opposite them. Then Tormod again signed SAW on his forehead with his right hand, then pointed to the chipboard with his left hand. This time the staff could see his signing, and she reached out for Tormod's hand and confirmed that she saw his sign. The staff member had the skill to see his signing and relate it to the previous experiences of sawing and answered his sign SAWING and pointing.

\section{Nails and screws}

Both Tormod and Petter experienced making nails in the forge. They were both able to follow the procedure of creating a nail from an iron stick, applying heat in the forge, then hammering it, which resulted in changes to the iron. Cooling down the iron each step made it possible to follow the changes in the development of the nail. Both Petter and Tormod showed great interest in the nail taking more the 20 min exploring the nail they had just made.

Petter showed in many ways that this aspect of the work was meaningful to him. An example from early in the project, when the first walls where created in the working area and the project had been focusing on nails and screws, he felt the different characteristics of them. The work included nailing using a hammer, screwing using a screwdriver, and of course a lot of tactile talking and tactile dialogues about tools, materials and actions. We discussed how to make sensible and meaningful tactile signs from Norwegian sign language. One morning the carpenter and Petter had been working 
together for a long period, and the wall was finished. Petter and his teacher explored the wall with the fingertips in details. Then Petter felt the wooden surface, and the tops of nails which had been hammered into the wood. Then his finger reached the top of a screw. Petter stopped and explored it carefully. With the other hand he made a sign. The hand shape like holding an electric screwdriver, and his index finger moving the way you adjust the speed of the screwdriver. This was a new sign for talking about the action. We had previously made a sign for screwing by making circles with our index finger on the hand of the other. Now Petter commented on the activity of using the screwdriver the way he had experienced the activity. Not only the iconic hand shape of holding the tool, but also using active iconicity to describe how the action was experienced by him. This sign was detected on the video afterwards, and the whole group started using Petter's sign for the screwdriver-activity.

This example shows a lot about Petter's skills. It also shows that the work was meaningful to him. If the exploration of the wall was not in this detail or if it was only a task told by the teacher, the new sign would not have been discovered. Using his tactile fingertip sensation in details like this, commenting on different aspects, and detecting small changes he is now familiar with, shows that he is not simply touching objects. He is using his fingertips for information and exploration and reflecting on details. Forsgren (2016) examines this hypertactile sensation further and used it as the basis for another categorisation of signs.

\section{Discussion}

In this discussion we will examine further four of the elements that seemed to be key in the success of the Bua-mi project: The authenticity and meaningfulness of the activities; the use of video footage; the collaboration between participants throughout the project; and the close link between practice and theory. These four elements were key to achieving the aim of language development.

\section{Authenticity and Meaningfulness}

We have seen in the literature that authentic and meaningful activities are key to communication development with people who are congenitally deafblind (Gibson, 2005; Ask Larson, 2013). But what does this mean, specifically related to this project?

A major lesson to be learned was the choice of focus, "Bua-mi", a small house. All the participants had an understanding of the concept "a house". The early activity of the project focused on gaining common ground by sharing knowledge and experiences of the concept "a house". These activities made sense for all the participants, including the support staff. It was easy to understand what was going on. Making trips to different 
houses and cabins expanded the knowledge, alongside developing the group dynamic and friluftsliv (outdoor living) skills. The topic of the house was important for scaffolding, both the language and the concepts in the minds of all the participants. Having a "simple" goal, to build a house, helped organize the work in a meaningful manner. The practical work on the house supported the communication amongst the participants and the importance of an accurate common language and common understanding was not just a nice by product but crucial to actually building a house.

The carpenter's knowledge of how to actually build the house supported the rest of the group in the building process. The key issue for this group was to keep the pace down with multiple repetitions. The carpenter's skills as a craftsman and the dialog between the participants made the conversation around the building crucial. It was important that all participants had the same understanding of the building process, had a common understanding. The creation of the house was the topic, and the experiences during the building were also a topic of conversations that took place alongside the work, in the breaks, and during the before and after-conversations. Using the unfinished house as a shed for breaks kept the topic alive as a scaffold. Within that scaffold we saw development of relationship amongst the participants. The real-time cooperation and the breaks were both important for relationships as a group and within the group.

\section{Use of video}

The recording and analysis of video footage was a key element of this project. There are however a number of negative aspects to the use of video footage in a project of this type. In section two the problems with analysing tactile communication, using an audiovisual medium (video), was highlighted. This was overcome by the analysis occurring as soon as possible after the events so the partners can add tactile information about the tension, the intensity or the strength of the hold and also who is leading and who is following movements. Another negative aspect of the use of video footage is that it is time consuming and resource heavy. It required a dedicated person to do the filming, and then the time to review all the footage and select clips to further analyse. Then once sections of interest were identified, there was the time to discuss them and agree on the how to progress. The footage then needs to be organised and stored for later use all of which requires resources. There was also an issue specific to this project. At the outset this was a practical project with educational and pedagogical aims but now the footage is also being used as research data. Even though there was no protocol on how the video footage should be systematically collected and analysed, it has still proved to be an invaluable source of data.

Nevertheless, these issues aside, using video footage with people who are congenitally deafblind, especially when assessing communication is vital. The signs and 
gestures noticed and developed as a part of the Bua-mi project were only possible through the use of video footage. The footage has also been used to share the stories of the project and disseminate the findings. Sharing the footage has also enabled collaboration with other professionals who were not part of the original project which can bring alternative wider views to the analysis. Mobile technology now enables easy collection of video footage from multiple sources. The process of daily reviewing and discussing the footage collected, although resource heavy, was crucial in creating an immediate feedback loop to the support staff and was able to close the gap between workers on the floor and project leader. This in turn aided the process of collaboration.

\section{Collaboration}

From other disciplines we know that collaboration helps to develop subjects. In this project, we came to learn, experience and understand the effects of synergy in practice. People with different skills and backgrounds met to take part in the work with a common target, to create meaningful activities to support language development. Tormod's staff team had lots of ideas about practical activities. The carpenter had the knowledge and skills to build a house. Petter's team had sign language skills and a pragmatic learning process for students with deafblindness. The professionals from the deafblind field had a theoretical background in language development in children with vision and hearing loss, and the ideas of how to focus on tactile experiences and communication. There were no assumptions made about any of the participants' understanding or knowledge within any area and as such all processes started at the basic level.

A possible weakness with interdisciplinary working, especially with disparate staff with a wide range of skills, is the risk of over dependence upon each other for certain tasks. Involving lots of people with specialist skills comes with the risk that one or more might be absent which could cause problems for the project. Indeed, such an occasion occurred, even though this proved to be positive in the long run. One day the carpenter had to stay home as his cows were calving. This situation was initially very difficult for Petter and meant the plans for the day had to be abandoned. However, the initial problem became a development opportunity because it allowed the team to talk about sad feelings and develop the skills to have dialogues about difficult emotions. The very real and authentic story was told and reflected on. Good teachers and staff seldom plan for bad experiences but they were able to take advantage of one that occurred in real life. Acknowledging the negative feelings and placing them within a supportive frame, it is possible to sort out and be given words and a story to tell.

The collaboration has now extended beyond the original participants. One experience from the project has been the basis for a Master thesis at the University of 
Groningen with analyses of Heightened Tactile Perception and Sign Development (Forsgren, 2016). When the Deafblind International Outdoor Network joined the project important theories for understanding the processes were added, and new possibilities for using Bua-mi and the surroundings in different meaningful activities were explored.

\section{Link between practice and theory}

The project started as a practical challenge and was created from a practical perspective based on the needs in a residential home. The initial ideas were supported by theoretical knowledge and experience in the area of communication development with people who are congenitally deafblind. New theoretical angles were discussed as time progressed and questions about the work and outcomes led to more theoretical discussions. It was reassuring to find the theories we brought to the project in the beginning remained relevant as the project progressed for example the importance of authenticity (Gibson, 2005), Scaffolding (Vigotsky, 1986) and Activity Theory (Engeström, 1987). The theoretical frames gave new aspects to our practical work, made it more consistent and made us more secure in why and how we should go on with the work. It was then possible to present the work in professional forums, explaining the ideas from both the practical work and the theoretical angle. Not only could theory enlighten the practical work, we could also give good practical examples documented by video explaining theories.

\section{Conclusions}

The Bua-mi project taught the professionals more than was expected in advance. The variety of skills the different participants brought and shared during the work, added much more to the total result than had been planned. Working together with people from diverse backgrounds was inspiring, and it was easy to implement ideas on all levels. The culture of collaboration and willingness to value the input of all the participants is something that is transferable across many other working groups.

The attitude of the staff to the deafblind participants was very positive to begin with, but by using video footage enabled even the experienced team members to improve their skills and recognise the skills of their deafblind partners. Confidence in their communication practice also increased through both exposure to good practice and the theoretical underpinning of the project. This in turn resulted in changed expectations and better communication situations for both Petter and Tormod.

While Tormod could interact regularly with the actual Bua-mi, Petter was restricted to just the project weeks. However, his teachers worked hard to bring the project back to school in a practical sense by making a Bua-mi model. This allowed opportunities to practice the skills and talk about the materials, tools and tasks that 
made up the project. The video footage was also used to share the stories and signs generated by the project with the other teachers at the school. Nevertheless, it has been the less tangible things that the teachers felt was the most important aspects of the project. The authentic emotions generated that could be discussed, labelled and talked about and the relationships developed, between Petter and Tormod. Even if sometimes this manifested as jealousy, this is still an authentic emotion! With Kjell Erik, the carpenter, Petter was able to experience excitement and mastery as well as disappointment. With his teachers Petter spent whole weeks away working on the project, not just school hours! There were also the other aspects of being away from home, travelling and mealtimes for example, as well as all the follow up sessions back at school.

Tormod and his team learned the tactile signing principles from Petter and his team, by watching their communication practice over time. They learned concrete skills such as switching from listening hand to speaking hands, and how to better negotiate a shared understanding. The increased skills means Tormod now expects more from his partners. They now pay more attention to his exploration, even if it takes a long time. He knows he can negotiate with them, using his body and the space to tell his intentions and stories. The team now regularly uses video recordings as a tool for better understanding, analyses and sharing experiences. The methods in this project was implemented in everyday life and is still alive several years after.

Developments do not happen overnight. Building the understanding of the world, creating good relationships and authentic stories take time. It needs authentic experiences, many repetitions and space for reflections, and the scaffolding needs to be secure at each stage. This is true for all, and for persons with congenital deafblindness we know it takes a huge amount of extra time to capture all the impressions through the sense of touch.

The method of the project was developing and fluid for all the participants. It could not happen in a classroom, working one - to -one inside four walls. It is probably not possible to copy this project exactly in your own landscape. You have to create something suitable for your own participants and environment. However, the principle of creating something from the bottom, making it meaningful and interesting, cooperating across professions, using video recordings and closely linking the practice with the theory can be used as a method. The authenticity is created by the natural events which are parts of the lived lives.

The Bua-mi project was a dynamic process giving positive effects everyone could be proud of and which none of the participants - person with deafblindness, staff or professionals - could gain by themselves. We believe working in the way highlighted in 
the project could also be transferred to other groups of persons with learning difficulties and other language development issues.

We were asked throughout the Bua-mi project if it was necessary to have such a large scaled subject (building a house!). What we learned was that choosing a project, where the end result was physical, concrete and known to all participants, was important, more important than we knew in the planning period. The legacy of the process and Bua-mi itself, first as a learning arena and now a place for visiting contains so many memories and is of immeasurable value. The next goal is to build a boat. Like Bua-mi the boat rests on the culture of the area in which it is built. In so many aspects this is the core which made Bua-mi a success and will be key to finding the right subject for those working on similar projects.

\section{References}

Andersen, WH \& Klingenberg, C. (2008). CHARGE syndrome. Journal of the Norwegian Medical Association, 128 (12), 1401-5. Retrieved 23rd October 2017 from http:// tidsskriftet.no/2008/06/oversiktsartikkel/charge-syndromet

Ask Larsen, F. (2003). The Washing-Smooth Hole-Fish and other findings of semantic potential and negotiation strategies in conversation with congenitally deafblind children. M.A. Thesis in Cognitive Semiotics. Århus, Denmark. Available in CNUS text no 9 https://nordicwelfare.org/en/publikationer/the-washing-smooth-holefish/

Ask Larsen, F. (2013). Acquisition of a bodily-tactile language as a first language. In J. Dammeyer \& A Nielsen (Eds.), Kropslig og taktil sprogudvikling [Bodily and tactile language development], (pp.91-119), ISBN 978-87-92574-22-0. Materialecentret, Aalborg, Denmark.

Brede, K. S. (2013). Språkutvikling gjennom meningsfull aktivitet. [Language development through meaningful activities]. Taktil kommunikasjonsutvikling hos en person med medfødt døvblindhet i tilknytning til bygging av Bua-Mi Prosjektrapport 1:2. Eikholt. Norge. Retrieved 3rd November 2017 from http:// wpstatic.idium.no/eikholt.no/2015/09/ISBN-978-82-998958-3-5-Språkutviklinggjennom-meningsfull-aktivitet-1-av-2-Ebok.docx.pdf

Brede, K. S. (2014). Språkutvikling gjennom meningsfull aktivitet-videreføring. [Language development through meaningful activities - continuation] Taktil kommunikasjonsutvikling hos en person med medfødt døvblindhet i tilknytning til bygging av Bua-Mi. Prosjektrapport 2:2, Eikholt. Norge. Retrieved 3rd November 2017 from http://wpstatic.idium.no/eikholt.no/2015/09/ 
ISBN-978-82-998958-5-9-Språkutvikling-gjennom-meningsfull-aktivitet-

Videreføring-2-av-2-Ebok.pdf

Engeström, Y. (1987). Learning by expanding: An activity-theoretical approach to developmental research. Helsinki: Orienta-Konsultit.

Forsgren. G.A.G.C. (2016). The Emergence of sign constructions based on heightened tactile perception. The Proposition of a New Sign Category. Master of Pedagogical Science, Communication and congenital deafblindness, University of Groningen, The Netherlands.

Gibson, J. (2005). Climbing to communicate: An investigation into the experiences of congenitally deafblind adults who have participated in outdoor education. Unpublished PhD Thesis. University of Strathclyde, Scotland.

Langacker, R. W. (2006). Grammer and conceptualization. Berlin: Mouten de Gruyter. Mesch, J. (1994). Døvblindas teckenspråk. En pilotstudie. [Deafblind sign language. A pilot study] Stockholms Universitet, Institusjonen för lingvistik, Sweden.

Nafstad, A. Rødbroe, I. (1999). Co-creating Communication. Dronninglund, Denmark. Forlaget Nord-Press.

Raanes, E. (2006). Å gripe inntrykk og uttrykk. Interaksjon og meningsdanning i døvblindes samtaler. [To grasp impressions and expressions. Interaction and meaning making in deafblind peoples conversations.] PhD, Trondheim, Norway.

Selvik, A. K. (2006). Spatial paths representing time: A cognitive analysis of temporal expressions in Norwegian sign language. PhD, Department of Linguistics and Scandinavian Studies Faculty of Humanities, University of Oslo, Norway.

Vygotsky, L. (1986). Thought and Language. Cambridge, Mass.: The MIT Press. ISBN-13: 860-1416745183.

Joseph Gibson, Co-ordinator Deafblind International Outdoor Network, Norway; e-mail: <deafblindoutdoors@gmail.com>. Kari Schjøll Brede, Supervisor Eikholt National Resource Centre for the Deafblind; Norway; e-mail <kari.s.brede@eikholt.no>. Grete A. Steigen, teacher Skådalen School for congenitally deafblind, Norway; e-mail< grete@johnsgard.no>. 